\title{
The Breathing Catastrophe: COVID-19 and Global Health Governance
}

\author{
Nicoletta Dentico ${ }^{1}$
}

Published online: 13 July 2021

(c) Society for International Development 2021

\begin{abstract}
In the second year of the pandemic, the malaise of global health governance has come to the fore at the intersection of the trajectories of global crises that have converged in 2020: the soaring inequalities, the climate disaster and the effects of a globalization that takes our breath away. COVID-19 puts into question most of the global health assumptions and reaffirms the political intuitions of the 1978 Alma Ata Declaration on primary health care, which positioned health at the centre of a public sector-led project for economic transformation and human dignity, based on human rights. The new coronavirus imposes a new sense of purpose to health policymaking, which is not yet captured in the current failed global response to the pandemic. This is also an opportunity for the international community that believes in public health and the role of public institutions, to re-imagine itself and project new creative ways to engage beyond classical models, so as to reconquer some ground for a healthier future.
\end{abstract}

Keywords Alma Ata declaration · Right to health $\cdot$ Global health $\cdot$ Pandemic $\cdot$ Health security $\cdot$ World Health Organization (WHO) $\cdot$ Multi-stakeholderism $\cdot$ ACT-accelerator $\cdot$ Vaccine inequity

As never before in history, common destiny beckons us to seek a new beginning. Let ours be a time remembered for the awakening of a new reverence for life (Pope Francis).

In 2020, three historic trajectories of incremental crises have come together taking the world's breath away: the COVID-19 pandemic, the climate emergency and rising inequalities. The most immediate of these forces is the novel coronavirus, which has magnified the structural frailties of political systems and the value frame of globalization, including in so-called advanced democracies, in collectively terrifying but individually unsurprising ways. Humans have so brutally altered the environment that we have become agents of transformations we cannot reliably control.

We are now in the second year of the pandemic, yet the path out remains unclear despite the high-sounding optimism of some world leaders (Catterall 2021). Successive highly contagious mutations threaten to hinder the progress made by vaccines, which were brilliantly produced after a lightning-fast quest last year. The World Health Organization (WHO), for its part, is still grappling with vaccine nationalism as it attempts to keep up with the rapidly evolving science surrounding COVID-19. The UN health agency continues to struggle to persuade countries to abandon their greed and help get vaccines where they are most needed. But nobody heeds the call; the vaccine success that Boris Johnson was boasting about, praising greed and capitalism, was not the international research and development of the vaccines and their subsequent production, but the vaccines' roll-out in Britain.

But there are new trends that emerge in global health after COVID-19, accelerated by the considerable transformations in 2020 . These are increasingly defined by aspirations that aim to expand the notions of health and social justice to encompass planetary, racial, gender and digital justice. While it seems obvious that a new set of organizing principles, institutions and norms will have to stem from this conjuncture, if we want to project the possibility of survival for humankind and other living beings, will today's crises inspire the international community to follow new concepts, values and priorities beyond market calculations and economic growth goals?
Nicoletta Dentico

ndentico@sidint.org

1 Society for International Development (SID), Rome, Italy 


\section{Wading Through a Storm of Governance Contradictions and Side-Tracking}

The ideological dismantling of public health systemsparticularly in Europe-and the widespread privatization of healthcare services in the USA and most low- and middle-income countries (LMICs) have transformed the virus into a social catastrophe for humanity and a major threat to our globalized economy (Michel 2020; Pueyo 2020). No country has ever set in place real emergency preparedness measures-prevention has never whetted economic appetites-which has resulted in overall shortages of essential public health tools such as tests, masks, ventilators, personal protective equipment (PPEs), and so on. The privatization syndrome has also made national health authorities ignore repeated warnings from the science community about animal wet markets, climate change and the arrival of the big virus (Dentico 2020). A good 18 months into the COVID-19 pandemic we now know: this ideology kills.

The new coronavirus did not come to break globalization. It came to reveal what was already broken. Even before the pandemic, globalization was in trouble. Its critical bodyblows in the new millennium-as epidemics of the SARS, MERS, Ebola, H1N1 viruses appeared-have exposed an extensive failure to realize the ideals of endless economic expansion and private wealth creation, in the scenario of a liberalized financial system. Today, as the pandemic continues to unfold as the "worst human and economic crisis of our lifetimes', according to UN Secretary-General António Guterres, its burden collides with the slow progress on achieving the Sustainable Development Goals (SDGs). ${ }^{1}$ The number of people left behind in efforts to achieve the SDGs is soaring: global food prices rose $20 \%$ in the last year (January 2020-January 2021), and COVID-19 is estimated to have dramatically increased the number of people facing acute food insecurity in 2020-2021. A locust outbreak is further compounding this crisis across 23 countries, with 272 million people estimated to be already or at risk of becoming acutely food insecure (World Bank Group 2021). Contrary to voiced optimistic projections, climate change is occurring faster than predicted despite the human lockdowns. ${ }^{2}$

In broad political terms, the virus has definitely come to uncover the grave form of bipolarism affecting the international community, torn apart by the violent spread of multiple disparities around the world and the aspirational mode towards socio-ecological sustainability by 2030 , in a governance scenario that refuses to address the pathogenic

\footnotetext{
${ }^{1}$ https://sustainabledevelopment.un.org/content/documents/26158 Final_SG_SDG_Progress_Report_14052020.pdf.

2 https://public.wmo.int/en/media/press-release/climate-change-indic ators-and-impacts-worsened-2020
}

neoliberal drivers of injustice. ${ }^{3}$ It has been calculated that without fundamental changes in the world's economic architecture it would take 207 years to eliminate poverty with the SDG strategy of global growth; the global economy would have to expand 175 times its present size (Hickel 2018) clearly, an impossible scenario. If ever such exorbitant growth were possible, it would expeditiously drive climate change to catastrophic levels and immediately reverse any gains against poverty. Yet, economic growth remains the mantra of SDG 8 on growth and employment; its first target is measured by metrics of 'sustained per capita economic growth' which are doomed to leave people behind when little or no measures are set in place to equitably distribute wealth and invest in social sectors. The focus on GDP growth will have dire consequences for the pursuit of healthy lives (SDG3). Under the influence of policy guidance or virtual conditions placed by the International Monetary Fund (IMF), governments find themselves at odds when having to deal with the drastic incompatibility between SDG 8 and SDG 3 (Meurs et al. 2019). A radical new synthesis would be needed, as the Club of Rome pinpoints in a recent analysis that substantiates the intrinsic contradiction between the socio-economic objectives of the SDGs (SDGs 1-11) and the environmental ones (SDGs 13-15). Justice and fair distribution should be prioritized, the Club of Rome says, in implementing the SDGs (von Weizsäcker and Wijkman 2018). Doing so would produce a vast amount of healthy outcomes.

The overall existing approach to achieving the SDGs fails to recognize that global impoverishment and ill health are the result of extreme wealth accumulation and overconsumption by a few, and does not consider that wealth concentration also favours political inequality by expanding the ability of corporate and financial élites to exercise their influence on policymakers to protect their economic privileges. Higher levels of inequalities are then bound to be transferred onto the next generations, culminating in deeper disparities and injustices. Yet, tackling the structural drivers of unsustainability is not a priority of the SDG approach. On the contrary, the goals and targets promote more unhealthy trade liberalization and enhanced power of the World Trade Organization (SDG 17.10), including bilateral free trade agreements. Instead of demanding a termination to the financial speculation that has caused food prices to spike since 2007 and relegated millions of people to hunger, the SDGs

\footnotetext{
${ }^{3}$ In its May 2016 flagship report Finance \& Development, the IMF featured a cover story by J. Ostry, P. Loungani and D. Furceri, 'Neoliberalism: Oversold?', a belated recognition of the extent to which the neoliberal policies that they had helped to spread globally had in effect exacerbated inequalities, while failing to stimulate much growth, https://www.imf.org/external/pubs/ft/fandd/2016/06/pdf/ ostry.pdf..
} 
target the need to ensure 'the proper functioning of food commodity markets'. ${ }^{4}$ There is no call for robust regulation of capital flows, nor do the SDGs, beyond aspirational references, propose pathways to concretely tackle tax avoidance and the several routes of illicit capital flows. Debt service alone drains something like US $\$ 700$ billion per year out of developing countries, where poor health care systems are the norm. But debt cancellation is not mentioned anywhere, while SDG target 17.4 mandates 'debt financing, debt relief and debt restructuring, as appropriate'. Meaning that not only debts will not be cancelled, but that they will be prolonged (Hickel 2015). According to development economics expert Jan Vandemoortele, one of the architects of the MDGs, 'These omissions are not due to an oversight; they are intentional. Regulating the food industry, the financial sector, the labour market $[\ldots]$ do not quite fit within the dominant economic narrative and do not rank high as priorities of most governments' (Vandemoortele 2016).

And what if COVID-19 had come to crudely warn the world that these contradictions are in themselves unsustainable, that the 2030 Agenda cannot function with such incoherences and it is actually moving in the wrong direction? What, if the viral outbreak had come to signal the definite spillover effect of the divorce between what communities and societies essentially need-public services, essential workers, the common interest-and the lawless logic of hyper-globalization driven by the untamed narcissistic supremacy of financial markets? The timing of the COVID19 outbreak - 75 years after the creation of the United Nations and 25 years after the creation of the World Trade Organization-lends itself to thought-provoking interpretations. While it proves that there is a global society, beyond any doubt, it also imposes a reality check on the international dis-order raging throughout the world.

\section{From the Alma Ata Declaration to Davos: Lost in Pandemic}

In 1978, the Alma Ata Declaration ${ }^{5}$ situated health as the trigger of the call for a New International Economic Order. Since its inception, the WHO had been trying hard to practice its institutional belief about 'health' as the experimental ground of individual and peoples' rights, the terrain on which to pioneer the viability of democracy and participation, especially (but not exclusively) in the newly emerged, decolonized nations. As the first technical agency in the UN system, created even before the proclamation of the Universal Declaration of Human Rights (UDHR), the WHO was

\footnotetext{
$\overline{4}$ https://www.globalgoals.org/2-zero-hunger.

5 https://www.who.int/publications/almaata_declaration_en.pdf? ua $=1$.
}

the obvious instrument to advance the political agenda at that conjuncture. The epistemic concept behind Alma Atahealth as the most sensitive and unquestionable indicator of human dignity - was to try and implement a new scenario in which the promotion and protection of the right to health should gradually become the building block upon which economic development could be designed, at its intersection with social justice. The mobilizing Health-for-All by the Year 2000 horizon derived precisely from that aspiration. The WHO- as the public institution concerned with international health-would not then just make recommendations. It would provide operational instruments that countries could use in their national planning, when translating their commitment to national improvements in health.

Broadly speaking, with diversified approaches and implementations, primary health care (PHC) coupled with social protection was the strategy that Europe adopted under firm government control through the creation of universal public health systems, which were the most effective welfare institutions to advance societal progress in the aftermath of World War II. A number of countries in the Global South have tried to operationalize the PHC principles to trigger public welfare and democratic participation, through the development of effective policies that were implemented with sustained local and national leadership and appropriate resources. Where this has happened, the impact on the health of the population has been considerable (WHO 2003). ${ }^{6}$ But that political drive did not last long. The perspective of a bottom-up societal development organized through democratic structures had substantially changed already a few decades after the UDHR. It did not take long for the international community of States to become the expression and the channel of strategic (commercial and military) interests, a trend that manifested itself under the guise of a rapidly growing health market. The WHO did not remain idle in the face of what was coming. It tried to resist it as much as possible to safeguard its authority and competence while providing Member States with key elements of the armamentarium needed to withstand the pressure from the neoliberal models that the international financial institutions had started to impose (Tognoni and Macchia 2020).

For all the debate on 'adjustment with a human face', the indiscriminate application of debt stabilization and structural adjustment packages in Third World countries as a condition for obtaining loans (to deal with the debt crisis)

\footnotetext{
${ }^{6}$ World Health Organization, A Global Review of Primary Health Care: Emerging Messages, WHO, Geneva, 2003, https://apps.who. int/iris/bitstream/handle/10665/70199/WHO_MNC_OSD_03.01_eng. pdf;jsessionid=D730E1B75F2E84962AD55CC92FF511F7? seque nce $=1$.

7 https://opendocs.ids.ac.uk/opendocs/bitstream/handle/20.500. $12413 / 5651 / \mathrm{rg} 224$. pdf?sequence $=1$
} 
soon became the reality of drastic cuts in public spending and subsidies on food, health and education. The adoption of monetarist policies in the Global South implied a redeployment of labour and capital, the creation of new skills to participate in the market opportunities of the economic structures shaped by the Global North and the privatization of public services. The WHO itself gradually became an economy-driven entity. In the 1990s, the introduction of 'the global burden of disease' concept converted health into the venue of illness, a move which reversed the health political agenda towards greater dependence on criteria of economic compatibility (World Bank 1993). These decades of deregulation and privatization to boost development, consistently fuelled by the World Bank and the IMF through their conditionalities, have defined a dramatic shift in power balances, both at the national and international level. The ideological preference for disparaging social investment has consistently de-routed national governments from loyalty or accountability to human rights principles and their implications. With the World Bank and later the World Trade Organization having asserted their political orthodoxies as the overarching normative regimes for the development models and priorities-indifferent to the pandemic, the annual World Bank Doing Business Report stubbornly continues to issue policy prescriptions that obstruct developing countries' COVID-19 recovery efforts and squeeze their readiness capacities for future health emergencies (Sonkin and Muchhala 2021) - a new international economic order has no doubt been set in place. One that could not have been more different, and distant, from what the Alma Ata Declaration had advocated for!

The passage from international health to the epistemology of global health in the 1990s indexed these political transformations and their geopolitical arrangements. Deriving its roots from public health and international health, the concept of global health was intended to incarnate the growing understanding that health transcends national boundaries and actors, and that transnational determinants like war, climate and neoliberal policies were at the origins of chronic inequities and their pathogeneses. Only large-scale perspectives were required to manage the scope of the problems. An immediately fashionable refrain, global health has nonetheless been a contested approach since its inception as a field of practice over 20 years ago (Koplan et al. 2009). As Randall Packard (2016) argues, global-health initiatives have saved millions of lives but have had limited effects on the overall health conditions of people living in underdeveloped areas, where healthcare workers remain poorly paid, infrastructure and basic supplies continue to be lacking; hardly any efforts have been made to highlight and address the underlying social and economic determinants of ill health. Global-health campaigns have mostly relied on the application of biomedical technologies-vaccines, insecticidetreated nets, vitamin A capsules-to attack specific health problems, but have failed to invest in lasting infrastructure for managing the ongoing health problems of local populations through local resources. 'Instead of levelling the playing field, global health has reinscribed colonial power differentials, as discourses, technologies and priorities tend to be set by agencies located in high-income countries (HICs) for export to the rest of the world' (Cousins et al. 2021). Ultimately, global health has come to refer increasingly to a small set of actors-non-governmental organizations (NGOs), philanthropic foundations and thinktanks, pharmaceutical and food companies, academia - that are presumed capable of defining the new health agendas needed for the poor, and the planet.

These players operate on the assumption of the shared responsibility of all stakeholders for global citizenship, the soothing semantics that legitimize the recent form of global governance called multi-stakeholderism. As governments at the UN have backed away from trying to manage globalization and take responsibility for the human rights agenda, multi-stakeholderism has gained incredible institutional support as 'the new normal' aimed at blueprinting a two decades' mushrooming of public-private partnerships (PPPs) under the aegis of a few donor governments and the corporate sector as the key modus operandi in health, in an annual sequence of announcements at the World Economic Forum in Davos (Gleckman 2018). These PPPs are now the most accredited players in global health, shaping a new form of partnership governance (Chan 2012) that is built on supple horizontal relations and contractual arrangements. This is replacing the intergovernmental power play based on a hierarchical legal setup (Gleckman 2018). Even in the emergency of a pandemic calling for the return of the big government, it seems impossible for the international community to step back and examine PPPs' effectiveness, and above all their legitimacy, as a dominant governance approach. At a time when the COVID-19 pandemic has resulted in massive market and governance failure in health (Williams 2020), governments and other international institutions remain more likely to call for a complicated multi-stakeholder mechanism to address the pandemic response than establish a multilateral body to manage the crisis, as we are witnessing with the COVAX arrangement to distribute vaccines to communities and peoples in developing countries.

\section{COVID-19: A New Sense of Direction for Global Health?}

Even before the arrival of the new coronavirus, the response to the sentinel epidemics of HIV/AIDS, Ebola or Zika showed that the world's 'therapeutic geographies' were deeply forged by histories of race, colonial legacies and postcolonial geopolitics. In the meantime, key factors such as the 
dismantlement of traditional multilateral arrangements, the sidelining of the impact of global warming, the increasingly stringent intellectual property rules and the dissemination of powerful but uncontrolled digital technologies are in many ways changing the meaning of 'health' and the implications of the 'global' in unpredictable ways.

Until now, the management of COVID-19 has ultimately reinforced the classical modes of the global health approach, particularly when it comes to the exclusive quest for biomedical solutions, the passive acceptance of the pivotal role of philanthropic actors and their peculiar method of pharmaceutical delivery through cost-effective interventions. Models that governments across the world have used to govern and control the contagion are built on recent developments in data science, contact tracing technology and artificial intelligence (AI), with a top-down exercise in surveillance and a technocratic mindset that underlies testing and tracking regimes in too many places today (Leonelli 2021). Under our eyes, COVID-19 has catalyzed and accelerated the pre-existing trend to revolutionize public health through digital technologies, with governments now investing in mass digital apparatuses, completely disregarding the dramatic inequalities in individual access to digital services and measures for data protection. It is a trend that evokes well the hyper-reality framework anticipated by the French philosopher and sociologist Jean Baudrillard, who foresaw the way in which the narrative of the pandemic was bound to lose its grip sooner or later, to be consistently replaced by its digital representation, in the excess of information which it generates. This phenomenon will make it more and more difficult to distinguish between the real and the unreal, people's health needs and the game, the virtual interface that is steadily supplanting the real world (Baudrillard 2015), as we see as the coronavirus pandemic is fast-forwarding the world into the fourth industrial revolution.

But that is only one part of the story. Indeed, there are defining aspects of global health beliefs that are being challenged by the new coronavirus. The breathing catastrophe has harshly reminded the world of the truth in the Alma Ata scope and arrangements. To the international community, it has again put the right to health and the multiplicity of determinants of health at the centre of the political agenda. COVID-19 is not simply a viral infection, but a complex synergistic epidemic, or syndemic with clinical and structural vulnerabilities entrenched by poor health, precarity and unemployment, deprivation and marginalization (Mendenhall 2020). In addition, planetary concerns related to biodiversity, climate and the threats posed by intensive animal agriculture as a driver of zoonotic diseases have potently made their way through the global health governance malaise. The global health arena has not yet distanced itself from the anthropocentrism that lies at the root of these interlinked crises, but a new aspiration for change in health values and practices is developing, based on the recognition of our interdependence with nature and with the fragility of the planet we live in (Hinchliffe et al. 2021).

National rather than global solutions have been at the core of the response. Nation-states have imposed quarantine measures and lockdowns, closed their frontiers, suspended their economies. Also, the uneven impact of the coronavirus has reminded us all of the difference between countries where sound national health systems exist (Germany, New Zealand, South Korea, Hong Kong, Taiwan, Viet Nam) and those where public health has been eroded through neoliberal approaches (UK, Italy, France, Spain, Brazil). As COVID-19 continues to spread among unprotected populations with the emergence of new and more contagious variants, we now see efforts by individual countries to strengthen their domestic healthcare systems and capacities, reshaping medical research infrastructures as matters of national security. The benefits of off-shoring medical production have been put into dire question, and increasingly some nations now work to rationalize the production of masks, hand-sanitizers, ventilators and medical equipment at home (Chung et al. 2020). Public R\&D and production of pharmaceuticals are back on the agenda of several governments as needed pathways for the future, for stronger universal health coverage systems linked to social protection (Tediosi et al. 2020).

With governments in the driver's seat, the COVID-19 pandemic has also induced a renewed recognition of the centrality of hard law in declaring and managing the health crisis, both at the national level-with the downside of pushing often nationalist agendas - and internationallywith the brushed up attention to the International Health Regulations (IHR) approved in 2005 after SARS. IHR are the sole binding legal instrument of global scale devoted to the prevention and the control of infectious disease spread, mandating countries to report on disease outbreaks and share information with the WHO and other Member States. ${ }^{8}$ The WHO has been globally criticized for having delayed the declaration of the COVID-19 as a Public Health Emergency of International Concern (PHEIC) - its highest alert level. Nevertheless the reality is that the majority of Member States have bluntly ignored the WHO's recommendations on a wide range of strategies to be used to contain the contagion-from contact tracing to vaccine solidarity, instead of stockpiling exorbitant amounts of immunization products to the detriment of low and middle income countries (Habibi et al. 2020).

Ultimately, the pandemic has pointed to the formidable wall of health discrimination and inequality that surrounds the culture of health institutions and healthcare settings, across the scalar levels of action (local and global). Routine

\footnotetext{
$\overline{8}$ https://www.who.int/publications/i/item/9789241580410.
} 
practices at country level have torn the veil of ideological contents of racism and colonialism, but exclusionary legacies have been diagnosed at the core of the global health enterprise, in a doubtful hierarchy of knowledge, as well. COVID-19 has ignited the recognition that global health legitimizes the hegemony of neoliberal values and contributes to the depoliticization of causes of ill health. In an international arena so heavily characterized by inequalities, the implicit function of the global health field is to confirm and replicate the existing power structures while announcing the explicit objective of improving population health and health equity (Kim 2021). Such tensions usually emerge in the material sites of national health systems, in the regulation and distribution of drugs and diagnostics, in the management of surveillance data and analytics, in the competing knowledge and expertise that inform global health governance (Abimbola 2021). But the pandemic has globally manifested new lines of collision, for example between the core value of social justice for the many health workers who were forcedly exposed to work without individual protections and compelled to ration scarce resources, and the proclaimed call for solidarity to respond to the pandemic. These tensions are constantly mounting, and with greater pressure, as the unequal vaccine distribution is being displayed as a form of apartheid, legitimized by institutional blessing (Gleckman 2021).

\section{Post-multilateralism and the Surge of Immuno-politics with COVID-19}

Never has the need for multilateralism been greater now that the right to health is back again as the most cogent route to people's lives and dignity. COVID-19 has taught the world that we are all vulnerable and interdependent. We are all in this together: not really in the same boat, as echoed by Pope Francis, ${ }^{9}$ but certainly in the same storm. However, the pandemic has also called into question the relationship between self and others, between the individual and the common, between proximity and distance.

The global pathogen that has shaken the world has disclosed political problems that demand political solutions. The response to the virus calls for unprecedented solidarity at global scale, since it is obvious after 18 months that no nation can handle the outbreak in isolation. It takes a state, social trust and leadership, writes Francis Fukuyama, to contain COVID-19 (Fukuyama 2020). However, the pandemic must deal with a world in disarray, a scenario that has been defined a 'non-system of international global governance'

\footnotetext{
9 https://religionnews.com/2020/03/27/pope-francis-only-togetherwe-can-do-this-during-extraordinary-indulgence-ceremony/.
}

(Gleckman 2018: 22). Indeed, the health response of governments has been far from brilliant. Several key players have indulged in inertia on how to tackle the virus, pretending that not much was happening. Buying time, in a sort of state of denial, they have lost control of the situation in their countries and contributed to the spread of the contagion (The Independent Panel for Pandemic Preparedness and Response, 2021). Mandatory inter-governmental cooperation was rapidly supplanted by a viral form of health sovereignty in recognizing and managing the disease outbreak - as for the violation of the WHO International Health Regulations mentioned earlier. Rather than cooperate for their mutual advantage, national governments have turned inward, bickered with one another, and identified external scapegoats for their own political failures. The WHO, since long deliberately weakened, has been trapped in the abrasive geopolitical tension between China and the USA, with President Trump's hazardous choice to depart from the world's only public institution on international health precisely when the USA was at the epicentre of the global COVID-19 spread. ${ }^{10}$ Of course, the decision of a key founding member to abandon the WHO has hit the world with a strong symbolic meaning. The most worrying indication is that the turbulence caused by COVID-19 and the overall poor, noncollaborative response of the international community to the pandemic, is likely to end up laying the justification for another final twist in global governance for health.

The hegemony of the World Economic Forum (WEF), which had formally institutionalized its role in the UN multilateral system just before the COVID-19 outbreak through the UN-WEF partnership, ${ }^{11}$ has advanced considerably due to the pandemic. The unexpected turn has ushered new clearance for the WEF 'Global Redesign Initiative' - a governance proposal somewhat unnoticed in multilateral circles and international social movements when launched in 2010 . It heralded its vision as follows:

Nation states and intergovernmental structures will continue to play a central role in global decision making. However, those institutions must be adapted to today's needs and conditions if they want to preserve their use and, hence, legitimacy. They must begin by more clearly conceiving of themselves as constituting just part of the wider global cooperation system that the world needs. In fact, they should work explicitly to cultivate such a system by anchoring the preparation and implementation of their decisions more deeply in the process of interaction with interdisciplinary and

\footnotetext{
${ }^{10}$ https://www.statnews.com/2020/05/29/trump-us-terminate-whorelationship/.

11 https://www.weforum.org/press/2019/06/world-economic-forumand-un-sign-strategic-partnership-framework/.
} 
multistakeholder networks of relevant experts and actors. $^{12}$

While the structural dynamics of the pandemic described earlier would entail the need to re-examine coexistence and reconceptualize the key categories of global health, the temptation to resort to the old knowledge regimes is immense and risks expanding beyond all proportion. That is what we are seeing as the pandemic unfolds. The 2020 WEF Great Reset Initiative, designed to operationalize the Global Redesign Initiative based on the need to improve the state of the world at a time when 'the Covid-19 crisis, and the political economic and social disruptions it has caused, is fundamentally changing the traditional context for decision-making, ${ }^{13}$ has now definitely affirmed 'a new contract'. ${ }^{14}$ Intergovernmental legal frameworks and institutions have now definitely accepted being not the sole, and not the most crucial component in the international arena. Throughout the COVID-19 crisis, the WHO administrative networks have been systematically used by WEF delegations accompanying WHO officials to Africa and other regions of the Global South, in most of the agency's COVID-19 initiatives to support health authorities and provide muchneeded equipment. In Geneva and other Western capitals, the fundamental change in the decision-making process has been tested in the arrangements to foster the race for developing the COVID-19 remedies. The international cooperation schemes to tackle the pandemic have been assertively designed by a few financial groups and prominent players, such as Bill Gates-the pre-eminent kingmaker of scientific mobilization against the new coronavirus (Zaitchik 2021).

At the very inception of the would-be pandemic, when the WHO had gathered already enough intelligence to be seriously concerned, the primordial premise was that the world would unite against the virus. The WHO assumption then was that the scientific community would maintain broad and open channels of communication since collective intelligence and information-sharing minimize duplication and accelerate discovery. ${ }^{15}$ The research experts gathered by the WHO also drew up plans for global comparative trials overseen by the agency, with the goal of assessing the respective merits of treatments and vaccines - the overarching assumption being that cooperation would define the global response, with the WHO playing a central role. That

\footnotetext{
12 https://it.scribd.com/document/39238804/Global-Redesign-Stren gthening-International-Cooperation-in-a-More-Interdependent-World.

13 https://www.weforum.org/great-reset.

14 https://www.weforum.org/great-reset.

15 https://www.who.int/news-room/events/detail/2020/02/11/defau lt-calendar/global-research-and-innovation-forum-to-mobilize-inter national-action-in-response-to-the-novel-coronavirus-(2019-ncov)emergency.
}

is where the solidarity-driven WHO COVID-19 Technology Access Pool (C-TAP) ${ }^{16}$ derives its origin. This vision ${ }^{17}$ has been outmatched and outmaneuvered by the most powerful player in the arena of global health, Bill Gates. In April 2020 Bill Gates launched his bold bid to fashion the world's scientific response to the pandemic, the COVID-19 ACT Accelerator, ${ }^{18}$ a new public-private partnership based on charity and industry enticements, purposedly aimed to divert innovative solidarity calls from science-sharing and confirm the status-quo vision for organizing the research, development, production and distribution of treatments and vaccines. In sharp opposition to the WHO C-TAP, the ACT Accelerator distils Gates's long-standing intellectual property doctrine - that intellectual property rights monopolies do not represent an obstacle to meeting global demand or ensuring equitable access and they must be protected even during a pandemic. The ACT-Accelerator also interprets a new reductionist interpretation of the multi-stakeholder notion. The role of the WHO is hijacked to a mere convening function-with the choice of former CEO of GlaxoSmithKline as special WHO envoy on COVID-19 (Taylor 2020). Civil society organizations are pretty much removed from the scene. The Foundation-driven public-private partnerships - the Global Alliance for Vaccines and Immunizations (GAVI) and the Coalition for Epidemic Preparedness Innovations (CEPI) - form the ACT-Accelerator's core engine, in alliance with the Wellcome Trust and the pharmaceutical industry. The key component of the one international existing scheme to fight the pandemic, the COVAX Facility for the research and production of COVID-19 vaccines, codifies the zero-sum vaccination battle that excludes the weakest and hits the poorest (Gleckman 2021) while the proposal to waive drugmakers' intellectual property rights to enable LMICs to make generic versions of vaccines and medicines has reignited decades of tensions in the global health arena.

\section{The Immunity Paradigm and the Management of Risk}

The disparity between the protected and the helpless-a challenge to any idea of justice-has never been so blatant: WHO Director General Tedros Adhanom Ghebreyesus has portrayed it as 'a shocking imbalance'. ${ }^{19}$ This insidious

\footnotetext{
16 https://www.who.int/initiatives/covid-19-technology-access-pool.

17 Speaking in the name of pharmaceutical companies Albert Burla, Pfizer CEO, called the C-TAP proposal 'a nonsense... and it's also dangerous': 'Pharma leaders shoot down WHO voluntary pool for patent rights on Covid-19 products', Stat, 28 May 2020, https://www. statnews.com/pharmalot/2020/05/28/who-voluntary-pool-patentspfizer/.

18 https://www.who.int/initiatives/act-accelerator.

19 https://www.bbc.com/news/world-56698854.
} 
management of the new coronavirus confirms a governance setup led by a new rigid hierarchy of technical solutionism and an uncritical acceptance of whatever 'expert knowledge' offers as the most viable and effective solutions for policymakers. Quite comfortably, with the excuse of pandemic surveillance and response, the élite of the biomedical community are taking advantage of the global pathogen to articulate the nature of viral threats through the logic of immunity that moves health securitization forward. Immunity is manifesting as the new organizing principle, the new ideology, in a scenario where humans continue to be the main aggressors. As Italian philosopher Donatella Di Cesare points out,

medicalization continues to serve as the mirror of selective closure, of convinced rejection of participation, of stubborn conservation. Immune systems are the security systems specialized in the protection and defense from invisible invaders, the migrant viruses that pretend to advance their occupation of the same biological space. The mirage of immunity proceeds, step by step, with globalization (Di Cesare 2020).

This construction of the immunity paradigm is not merely a metaphor, and it goes beyond biochemical categories. It embraces the socio-political and juridical factors, as we now see in the proposal formulated at the WHO Executive Board of a pandemic treaty. German sociologist Ulrick Beck had anticipated this in his theory of 'the risk society' (Beck 2009). Risk distribution shows that, like wealth, risk conforms to prevailing class patterns and reinforces them. Poverty attracts an abundance of risks, whereas the wealthy (in income, power or education) can purchase safety and freedom from risk, or even profit from the risks by producing or selling the technologies that help prevent risks from occurring or deal with their adverse effects once they occur. The management of risk, ultimately, is the prime feature of the global order.

\section{Conclusions: What Can Civil Society Organizations Do, in the Shrinking Space of Global Health Governance?}

The state of malaise that affects health multilateralism reduces significantly the agency of civil society organizations. The raging tension between solving the global vaccine distribution problem from a human rights perspective, as the TRIPS Waiver proposal calls for, or from a World Economic Forum perspective, as the COVAX mechanism does-circumventing multilateral setups and confirming the pharmaceutical knowledge production market—is a good example of the pandemic management the world is confronted with, when the need for sensible rules of international cooperation has greater urgency than ever.
Where do we go from here?

The sea changes of 2020 call for new modes of action. The pandemic has shone an uncomfortable light on the lack of attention to the upstream drivers of health within the global health community, but it has proven the fundamental role of universal public health systems and the key role of the state in tackling the pandemic. Most importantly, it has displayed the interconnection that links together zoonoses, global warming and worsening inequalities, including geographical and racial ones. Health governance is challenged to redefine sustainability precisely in terms of these trajectories, ultimately in terms of health justice.

Civil society actors, health professional organizations and those who believe in the human right to health will also have to reconfigure and reinterpret their role in this arena transformed by the pandemic. There are stark choices to be made to relaunch the democratic space, after decades of traditional engagement within UN settings in this neoliberal context. Key steps in this direction include:

1. Opening political avenues at national/regional/global levels to discuss the definition of a new proactive agenda based on planetary health rights, as well as the nexus between health, social justice and finance (with propositions for debt cancellation and curbing of illicit financial flows);

2. Converging on news forms and tactics of engagement with policymakers and health institutions, to mobilize societal attention to the nexus between human health and climate justice-and the role of governments in shaping a new economic paradigm;

3. Creating public fora which may function as judicial courts-like the Permanent People's Tribunal-to provide excluded communities the space and the instruments to consider strategic litigations and seek appropriate remedies against violations of health rights at national and global level (particularly with the emergence of multistakeholder actors);

4. Opening the appropriate institutional paths with Member States to open new negotiations on the current landscape of global health governance, its effectiveness and accountability.

Predictably, the route to health justice is going to be a long journey, and an exhausting one. With ingenuity, resistance, and the courage of daring, we shall have to be united and smart enough to start crossing this desert. We have nothing to lose, and this might be our strength in the end. 


\section{References}

Abimbola, Seye. 2021. The uses of knowledge in global health. BMJ Global Health 6: e005802.

Baudrillard, Jean. 2015. In From Hyperreality to Disappearance: Uncollected Interviews, ed. R.G. Smith and D.B. Clarke. Edinburgh: Edinburgh University Press.

Beck, Ulrich. 2009. World at Risk. Polity Press.

Catterall, Pippa. 2021. 'Greed, my friends': has Boris Johnson finally revealed his political philosophy? LSE blogs, 29 March. https:// blogs.lse.ac.uk/politicsandpolicy/greed-my-friends/.

Chan, Sander. 2012. Partnerships Beyond the OECD: China and India. In Public-Private Partnerships for Sustainable Development, ed. Philipp Pattberg, Frank Biermann, Sander Chan, and Ay.şem Mert, 215-236. Cheltenham: Edward Elgar.

Chung, Calvin King, Jiang Xu Lam, and Mengmeng Zhang. 2020. Geographies of COVID-19: How space and virus shape each other. Asian Geographer 37 (2): 99-116.

Cousins, Thomas, Michelle Pentecost, Alexandra Alvergne, et al. 2021. The changing climates of global health. BMJ Global Health. https://doi.org/10.1136/bmjgh-2021-005442.

Dentico, Nicoletta. 2020. The COVID-19 Crisis In Health Systems \& Prospects For Recovery-The View From Italy, Health Policy Watch, 27 March. https://healthpolicy-watch.org/the-covid-19-crisis-in-health-systems-prospects-for-recovery-the-view-from-italy/

Di Cesare, Donatella. 2020. Virus sovrano? L'asfissia capitalista, Bollati Boringhieri, June.

Fukuyama, Francis. 2020. The Pandemic and Political Order. It Takes a State, Foreign Affairs, July-August. https://www.foreignaffairs. com/articles/world/2020-06-09/pandemic-and-political-order? utm_medium.

Gleckman, Harris. 2021. COVAX: A global multistakeholder group that poses political and health risks to developing countries and multilateralism, TNI Long Reads, 1 April. https://longreads.tni. org/covax.

Gleckman, Harris. 2018. Multistakeholder Governance and Democracy: A Global Challenge. Milton Park: Routledge.

Habibi, Roojin, Gian Luca Burci, Thana C. De Campos, Danwood Chirwa, Margherita Cinà, Stéphanie. Dagron, et al. 2020. Do not violate the International Health Regulations during the COVID-19 outbreak. The Lancet 395 (10225): 664-666.

Hickel, Jason. 2018. The Divide: Global Inequality from Conquest to Free Markets, 35-36. New York: W.W. Norton \& Company.

Hickel, Jason. 2015. The Problem with Saving the World, Jacobin. https://www.jacobinmag.com/2015/08/global-poverty-clima te-change-sdgs/.

Stephen, Hinchliffe, Lenore Manderson, and Martin Moore. 2021. Public Health Publics After COVID-19. The Lancet 5 (4): E230-E236.

Kim, Hani. 2021. The implicit ideological function of the global health field and its role in maintaining relations of power. BMJ Global Health. https://doi.org/10.1136/bmjgh-2021-005620.

Koplan, Jeoffrey, Christopher Bond, Michael Merson, et al. 2009. Towards a common definition of global health. The Lancet 373 (9679): 1993-1995.

Leonelli, Sabina. 2021. Data Science in Time of Pan(dem)ic, Harvard International Review, 3.1. https://assets.pubpub.org/zibcvxa7/ fbb1bdd6-7db1-4702-a41a-a25aa93d5c14.pdf.

Mendenhall, Emily. 2020. Why social policies make coronavirus worse, Think Global Health, 27 March 2020. https://www.thinkgloba lhealth.org/article/why-social-policies-make-coronavirus-worse
Meurs, Mariska, Lisa Seidelmann, and Myria Koutsoumpa. 2019. How healthy is a 'healthy economy': Incompatibility between current pathways towards SDG3 and SDG8. Globalization and Health 15 (1): 83.

Michel, Jean-Dominique. 2020. COVID-19: fin de partie?!, 18 March. https://jdmichel.blog.tdg.ch/archive/2020/03/18/covid-19-fin-departie-305096.html.

Packard, Randall. 2016. A History of Global Health: Interventions into the Lives of Other Peoples. Baltimore, MD: John Hopkins University Press.

Pueyo, Tomas. 2020. Coronavirus: The Hammer and the Dance. What the Next 18 Months Can Look Like, if Leaders Buy Us Time, 19 March. https://medium.com/@ tomaspueyo/coronavirus-the-hammer-and-the-dance-be9337092b56

Sonkin, Flora and Bhumika Muchhala. 2021. It's time for the World Bank to scrap its Doing Business rankings, Al Jazeera, 22 April. https://www.aljazeera.com/opinions/2021/4/22/its-time-for-theworld-bank-to-scrap-its-doing-business-rankings.

Taylor, Nick Paul. 2020. WHO tasks ex-GSK CEO Witty with hastening COVID-19 vaccine R\&D, Fierce Biotech, 15 April. https:// www.fiercebiotech.com/biotech/who-tasks-ex-gsk-ceo-witty-haste ning-covid-19-vaccine-r-d.

Tediosi, Fabrizio, Knut Lönnroth, Ariel Pablos-Méndez, and Mario Raviglione. 2020. Build back stronger universal health coverage systems after ther COVID-19 pandemic: the need for better governance and linkage with universal social protection. BMJ Global Health 5 (10): e004020.

The Independent Panel. 2021. COVID-19: Make it the Last Pandemic, The Independent Panel for Pandemic Preparedness and Response, May 2021. https://theindependentpanel.org/wp-content/uploads/ 2021/05/COVID-19-Make-it-the-Last-Pandemic_final.pdf

Tognoni, Gianni, and Macchia Alejandro. 2020. Health as a Human Right: A Fake News in a Post-Human World? Development 63 (2-4): 270-276. https://doi.org/10.1057/s41301-020-00269-7.

Vandemoortele, Jan. 2016. SDGs: the tyranny of an acronym? Impakter, 13 September. https://impakter.com/sdgs-tyranny-acronym/

von Weizsäcker, Ernst, and Anders Wijkman. 2018. Come on: Capitalism, Short-termism, Population and the Destruction of the Planet. Berlin: Springer.

Williams, Owen D. 2020. COVID-19 and Private Health: Market and Governance Failure. Development 63 (2-4): 181-190. https://doi. org/10.1057/s41301-020-00273-x.

World Bank. 1993. World Development Report 1993: Investing in health: World development indicators. Oxford: Oxford University Press.

World Bank. 2021. Food Security and COVID-19, The World Bank, 18 June 2021. https://www.worldbank.org/en/topic/agriculture/brief/ food-security-and-covid-19.

World Health Organization. 2003. A Global Review of Primary Health Care: Emerging Messages. Geneva: WHO.

Zaitchik, Alexander. 2021. How Bill Gates Impeded Global Access to COVID Vaccines, The New Republic, 12 April. https://newre public.com/article/162000/bill-gates-impeded-global-accesscovid-vaccines

Publisher's Note Springer Nature remains neutral with regard to jurisdictional claims in published maps and institutional affiliations. 